\title{
No net loss of what, for whom?: stakeholder perspectives to Biodiversity Offsetting in England
}

\author{
Oliver Taherzadeh ${ }^{1}$ (D) Peter Howley $^{2}$
}

Received: 21 January 2017/Accepted: 12 May 2017/Published online: 26 May 2017

(C) The Author(s) 2017. This article is an open access publication

\begin{abstract}
Market-based instruments (MBIs) have emerged as a popular approach to balance development and conservation objectives. However, their ability to accomplish this is often beset by poor implementation in practice. This is testament to a widening gap between the rate of policy development and implementation of MBIs and the maturity of research and evaluation on their design, and impact on affected stakeholders. Within this context, this paper examines multi-stakeholder perspectives to the adoption of Biodiversity Offsetting in England, an instrument designed to enable biodiversity losses in one place to be compensated through conservation improvements elsewhere. Analysis reveals issues associated with social and ecological compensation of biodiversity loss. Findings suggest that there is a need for a broader consideration of issues surrounding distributive justice, access to nature and the status of ownership over sites of common heritage when accounting for biodiversity loss and its compensation. This message is salient to both the study context as well as the burgeoning international practice of Biodiversity Offsetting.
\end{abstract}

Keywords Biodiversity offsetting $\cdot$ No Net Loss $\cdot$ Social justice $\cdot$ England $\cdot$ Conservation

\section{Introduction}

Markets are increasingly seen as both part of the problem and part of the solution in relation to contemporary environmental challenges. The emergence of markets in water quality, biodiversity and carbon sequestration is indicative of nature being subsumed within prevailing systems of commodity production and exchange (Robertson 2012). Such is the pace of this change that nature, people and their relationships are increasingly caught between the balance

Oliver Taherzadeh

oat24@cam.ac.uk

1 Department of Geography, University of Cambridge, Downing Place, Cambridge CB2 3EN, UK

2 Environment Department, University of York, Wentworth Way, Heslington, York YO10 5NG, UK 
sheets of national accounting systems and the yardstick of the market (Robertson 2000, 2004). The former tries to package nature into neat categories and functional units while the latter helps to translate these into a price that can be understood and traded by markets across geographical space (Dempsey and Suarez 2016). Some argue that this process overlooks broader values associated with nature (Braun and Castree 1998; Dempsey and Robertson 2012; Sullivan and Hannis 2015; Apostolopoulou and Adams 2017). However, others believe that creating markets of environmental goods and services has tremendous potential for maximising the protection of ecosystems and biodiversity (Balmford 2002; Sutherland et al. 2006; TEEB 2008; Kettunen and Vihervaara 2012; Helm and Hepburn 2014). They attest that, within the context of economic decision-making, nature has a null value, and is undervalued and over-exploited as a result (von Hase and ten Kate 2017). It follows, ascribing a value to nature presents a business cost to its extraction and bears a profit for its protection, placing markets, people and the planet on a corrective path for sustainable growth.

Within the context of biodiversity loss and ecosystem degradation, market-based instruments (MBIs) have emerged as a way to reconcile development needs and conservation objectives (Gómez-Baggethun et al. 2010; Reid 2011). The appetite for MBIs has risen in response to growing disillusionment with prevailing, non-market-based approaches to conservation (Redford and William 2009). Traditional forms of command-and-control regulation, which adopt a prescriptive and top-down approach to conservation, are viewed as inherently inefficient and inflexible, costly to enforce, and prone to regulatory capture (Mol et al. 2009; Pautz and Wamsley 2012). Conversely, voluntary approaches to conservation have had mixed results (cf. Santangeli et al. 2016 and McCarthy and Morling 2015) with their success highly contingent on the level of political will for environmental protection within the contexts they operate (Segerson 2013). Meanwhile, community-based conservation which integrates social development goals with conservation objectives has proved successful at a local-scale through bottom-up understanding of local cultural context in intervention success (Brooks et al. 2012; Waylen et al. 2010); however, such approach is limited when viewed against the backdrop of planetary-scale risks to ecosystems and biodiversity (Kellert et al. 2000; Barrett et al. 2001; Kiss 2004; Berkes 2007).

The widening gap between the rate of policy development of MBIs for conservation and the maturity of critical scholarship on their theoretical and practical implications increases the likelihood of ineffective and harmful policy interventions (Reid 2011; Roth and Dressler 2012). The modest achievements of projects on payment for ecosystem services (Landell-Mills and Porras 2002; McAfee 2012; Pokorny et al. 2013; Hejnowicz et al. 2014) and carbon offsetting schemes (Corbera and Brown 2010; Knox-Hayes 2010; Cavanagh and Benjaminsen 2014; Klinsky 2015) are symptomatic of this. There is currently poor articulation of the economic, institutional and ecological conditions in which MBIs for conservation are most effective (Robinson 2006; Gómez-Baggethun et al. 2010; Wissel and Wätzold 2010). There are also very few shared characteristics between different instruments, limiting their reproducibility across space (Pirard 2012). Extrapolating the success of one instrument or study site to another, in the absence of contextual information, often results in uneven success and implementation of approaches (Landell-Mills and Porras 2002). An empirical, case-specific inquiry is key in this regard.

This article examines stakeholder perspectives to the design and use of Biodiversity Offsetting, an infant conservation MBI, within conservation practice in England. It is based on in-depth interviews with key conservation stakeholders in England. The study area reflects the fact conservation practice in the UK is devolved within England, Scotland, Wales and Ireland. Responses were coded using a three-cycle approach to produce a conceptually rich understanding of the practical and theoretical challenges presented by 
Biodiversity Offsetting in England, which is currently lacking (Bull et al. 2013; Evans et al. 2015; Hackett 2016). Coding counts indicate that ecological compensation $(X=604)$ and social compensation $(X=593)$ are both important in the design and implementation of Biodiversity Offsetting.

\section{Theoretical and practical challenges to Biodiversity Offsetting}

In the last 50 years, England's ecological network has experienced mounting stress from economic development (Lawton et al. 2010). Over this period, 60\% of UK species have declined (Burns et al. 2013). Such a trend is particularly concerning given the link between biodiversity loss and degradation of ecosystem services which deliver cultural benefits (Fuller et al. 2007; Albon et al. 2014; Oliver et al. 2015).

Biodiversity Offsetting has been promoted by the English Government as a tool to appease the longstanding conflict between economic development and biodiversity conservation. Offering developers the chance to purchase credits from actions with positive biodiversity outcomes in order to "offset" adverse biodiversity impacts from their own development activities (eftec et al. 2010), Biodiversity Offsets are designed to ensure there is no net loss (or a net gain) in ecological value (Parliamentary Office of Science and Technology 2011). Biodiversity Offsetting is often referred to within the context of the mitigation hierarchy, a sequence of abatement stages to reduce negative biodiversity impact during development. Assuming attempts are made to reduce biodiversity loss, by avoiding and minimising impacts or addressing damage done through restoration (BBOP 2013), Biodiversity Offsetting is intended to compensate for any residual biodiversity impact. The use of Biodiversity Offsetting - and the application of the no net loss principle - is proposed to be applied to compensate for biodiversity loss specifically on non-protected sites of which current regulation permits in less than 1 in a 1000 planning applications (Baker et al. 2013). However, the UK's decision to leave the European Union may extend the reach of Biodiversity Offsetting to sites currently afforded protection under the EU Birds (79/409/ EEC) and Habitats Directive (92/43/EEC) unless commensurate protection is put in its place (European Commission 2008). In 2012, the UK Department for Environment, Food \& Rural Affairs (Defra) established a series of pilot sites around England, in Devon, Doncaster, Essex, Greater Norwich, Nottinghamshire, Warwickshire and Coventry and Solihull. These pilots, concluding in April 2014, tested the efficacy of Biodiversity Offsetting to deliver infrastructure development and conservation commitments for England in tandem (Defra 2013b). Discussion of the practical challenges associated with Biodiversity Offsetting provides a useful context to the issues exposed in this study.

From a temporal perspective, one major challenge Biodiversity Offsetting faces is permitting offsets where compensation for biodiversity loss occurs over an extended period (Bull et al. 2013), since processes such as soil formation, tree growth, and the development of biophysical habitats are slow relative to human time frames (Moilanen et al. 2009). Development of habitats is also inherently uncertain. To account for uncertainty and to satisfy no net loss criteria, offsets must be set at significantly higher ratios, in ecological terms, than the original sites destroyed (Moilanen et al. 2009; Pickett et al. 2013). However, observations show existing Biodiversity Offsetting schemes seldom deliver compensation stipulated by no net loss (Kettlewell et al. 2008; Robertson and Hayden 2008). The time lag between a development and an offset also presents ambiguity in determining how long the offset should be maintained, by whom, and whether this commitment could diminish if the political and legal landscape changes (Bull et al. 2013). 
The modest success of the US Mitigation Banking programme (EPA 2015), the longest running Biodiversity Offsetting scheme in existence, exemplifies the practical challenges associated with non-state actors mediating Biodiversity Offsetting. In the US state of Ohio, Kettlewell et al. (2008) found two-thirds of projects were unsuccessful in restoring the wetland area stipulated by their permit, and permits allowed different wetland types to be interchanged during compensation, resulting in net biodiversity loss. In Massachusetts, Robertson and Hayden (2008) found $21 \%$ of developers made no attempt at building the offset site, and schemes that were successful provided compensation at a lower overall ratio than non-bank forms of compensation. Meanwhile, a quantitative functional assessment of 40 riparian mitigation projects in Orange County, California, found none of the projects were "functionally successful", as defined by the successful restoration of hydrology, biogeochemistry and habitats (Ambrose 2000). Laurance et al. (2015) assert that biodiversity offsets are far too often used as a crude form of damage control in response to poorly conducted environmental impact assessments. Furthermore, there are several instances in which biodiversity cannot meaningfully be replaced with no net loss in ecological value, leading to irreversible loss of biodiversity (BBOP 2013); this is particularly true for mitigation involving translocation of species (Pilgrim et al. 2013).

A further caveat of Biodiversity Offsetting is demonstrating "additionality", the additional biodiversity gained from an offset site against a business-as-usual scenario (Maron et al. 2010; Bull et al. 2013). This requires appraisal of baseline biodiversity and ecosystem functioning to isolate the effect of the conservation intervention. However, detractors of Biodiversity Offsetting suggest that meaningfully evaluating such counterfactuals is unfeasible based on the 20-min site assessment recommended in the government guidance paper (Defra 2013b; Environmental Audit Committee 2013).

\section{Methods}

\subsection{Stakeholders}

Stakeholder groups and individual respondents were carefully identified with respect to their knowledge of, and engagement with the design and implementation of biodiversity offsetting in England. Extant literature, professional networks, and a corpus of news articles and editorials on Biodiversity Offsetting were used to identity suitable stakeholder groups and individual respondents.

At the time of data collection, grey literature was more abundant than peer-reviewed literature on the topic of Biodiversity Offsetting in England and revealed two key stakeholder groups working at the interface of science, policy and business. First, local planning authorities (LPA), which are responsible for overseeing compliance of Biodiversity Offsetting pilots in the England. Participants in this group were well positioned to explain the protocols involved in Biodiversity Offsetting and the practical challenges they face in an institutional policy setting. Second was offset brokers (OB): organisations and individuals commissioned by developers to administer biodiversity offsets; early research into biodiversity offsetting in England indicates such group is focal within the emergence of offset projects (Hannis and Sullivan 2012).

Using the search function of the LinkedIn online professional network (search terms: "Biodiversity Offsetting" and "Biodiversity Offsets"), we found a number of academic researchers (AR) with research expertise in the field of Biodiversity Offsetting and 
restorative ecology. Meanwhile, we identified one small (Save our Woods), one mediumsized (FERN), and one large (Friends of the Earth) environmental and social justice organisations all actively investigating the implications of Biodiversity Offsetting in England and the EU; this group was categorised as environmental campaigners (EC). In total, we interviewed 12 respondents, three in each of the four stakeholder groups (Table 1). Descriptions of participants are provided in "Appendix 1".

\subsection{Interview structure}

We used a combination of face-to-face and telephone interviews which were recorded with the permission of respondents and transcribed verbatim by the authors (see online supplementary material for full transcripts dataverse.harvard.edu/dataverse.xhtml?alias= biodiversityoffsetting). The interview protocol featured a series of open-ended questions in the form of a semi-structured interview guide (see "Appendix 2"). This was based on a synthesis of the literature and ongoing discourse around Biodiversity Offsetting. A key line of inquiry in interviews related to the "Defra metric" for Biodiversity Offsetting, composed of three criteria for calculating the level of ecological compensation ("biodiversity units") between a development site and offset site, as outlined in the Government green paper (Defra 2013b): habitat type, condition and area. This metric was principally chosen for its simplicity to assess and fulfil ecological compensation required after infrastructure development, although it's the strengths and weaknesses within the context of compensation for biodiversity loss were explored in more detail with respondents.

The interview guide for this study was amended after administering a pilot survey prior to the main round of interviews. We adapted the guide during the interviews based on the expertise of different stakeholders using memo notes and directed further questions to respondents to draw upon their experiences and concerns.

\subsection{Interview coding}

We subjected the interview transcripts to three rounds of coding (open, axial and selective) in order to realise the full value of the data and the underlying meaning of the responses (Strauss and Corbin 1991; Glaser and Strauss 2009). The first stage of coding-open coding-involved fracturing of data in order to examine, compare, conceptualise and

Table 1 Stakeholder groups, descriptions and abbreviations

\begin{tabular}{|c|c|c|}
\hline Stakeholder group & Description & Abbreviation \\
\hline $\begin{array}{l}\text { Academic } \\
\text { researchers }\end{array}$ & $\begin{array}{l}\text { Recognised experts in ecology who have also provided input to } \\
\text { consultations on Biodiversity Offsetting design and implementation } \\
\text { in England }\end{array}$ & $\operatorname{AR}[1,2,3]$ \\
\hline Offset brokers & $\begin{array}{l}\text { Prospective accreditation bodies responsible for brokering credit } \\
\text { trading in biodiversity offset credits in England between developers } \\
\text { and land owners }\end{array}$ & $\mathrm{OB}[1,2,3]$ \\
\hline $\begin{array}{c}\text { Environmental } \\
\text { campaigners }\end{array}$ & $\begin{array}{l}\text { Individuals representing environmental NGO organisations (large and } \\
\text { small) with active campaigns related to biodiversity offsetting in } \\
\text { England }\end{array}$ & $\mathrm{EC}[1,2,3]$ \\
\hline $\begin{array}{c}\text { Local planning } \\
\text { authorities }\end{array}$ & $\begin{array}{l}\text { Senior local government ecologists responsible for designing and } \\
\text { implementing Defra biodiversity offsetting pilot schemes in their } \\
\text { respective authorities }\end{array}$ & $\operatorname{LPA}[1,2,3]$ \\
\hline
\end{tabular}


extract meaning from participant responses (Strauss and Corbin 1991). This involves a line-by-line analysis of the interview transcriptions, where the analyst writes memos about conceptual and theoretical ideas which emerge during the analysis (Walker 2006). Axial coding is then used to reassemble data, by relating concepts (or subcategories) to broader, more abstract categories. During this exercise, the practitioner will begin to consider “...causal conditions, phenomenon, context, intervening conditions, action/interaction and consequences" (Halaweh 2012). Selective coding refers to the final stage of analysis; here, the analyst selects a core category as a vehicle for the subsumption of other categories (Benaquisto 2008). During this phase, the analyst can begin to construct a framework using themes from previous coding cycles (Bryman and Burgess 1994). The analytical product which emerges from this systematic coding process helps to integrate existing theory and build the analysts' research agenda by exposing new areas of scholarship (Dey 1999).

To illustrate the significance of different concepts highlighted during the coding process, the number of occurrences of a specific concept within interviews was recorded, denoted by $X=$ occurrence count.

\section{Results}

Two central themes emerged from analysis of the interviews: ecological compensation, which reflects the theoretical and practical challenges associated with implementing Biodiversity Offsetting; and social compensation, which captures the social justice and equity issues surrounding Biodiversity Offsetting. Below we outline the steps followed to characterise the stakeholder interviews. Section subheadings have been included at levels where it is useful to distinguish different sub-themes. Figure 1 depicts all themes within a coding tree.

\subsection{Ecological compensation}

Stakeholder interviews identified challenges surrounding implementation $(X=299)$ and valuing biodiversity $(X=305)$ as most important to the level of ecological compensation delivered within a Biodiversity Offsets. The theme of implementation reflected the regulatory environment $\{X=234\}$ surrounding Biodiversity Offsetting and how these were shaped by policy context $\{X=65\}$. Within the context of the regulatory environment for Biodiversity Offsetting, respondents identified several important factors: National context $\{X=61\}$; regulation of offsets $\{X=52\}$; the extent to which biodiversity offsetting strengthened $\{X=17\}$ or undermined $\{X=29\}$ the protection of nature and its effect on adherence to the mitigation hierarchy $\{X=28\}$; government versus governance in the management of Biodiversity Offsetting $\{X=23\}$; and, whether simplification of planning and development was likely to deliver greater protection of biodiversity $\{X=22\}$. In reference to policy context respondents reflected failures of the current system of planning and conservation practice $\{X=28\}$, the creep of neo-liberalism into the problemitisation of, and response to biodiversity loss $\{X=27\}$, and the extent to which Biodiversity Offsetting was given greater credence as a policy instrument as a result of austerity and its impact on the regulatory resources of local authorities $\{X=10\}$.

The theme of valuing biodiversity relates to the proposed parameters when calculating biodiversity offsets $\{X=208\}$, reflecting issues of equivalence $\{X=40\}$, proximity $\{X=36\}$, the simplicity of Defra metric $\{X=31\}$, uncertainty $\{X=28\}$, base lines and 

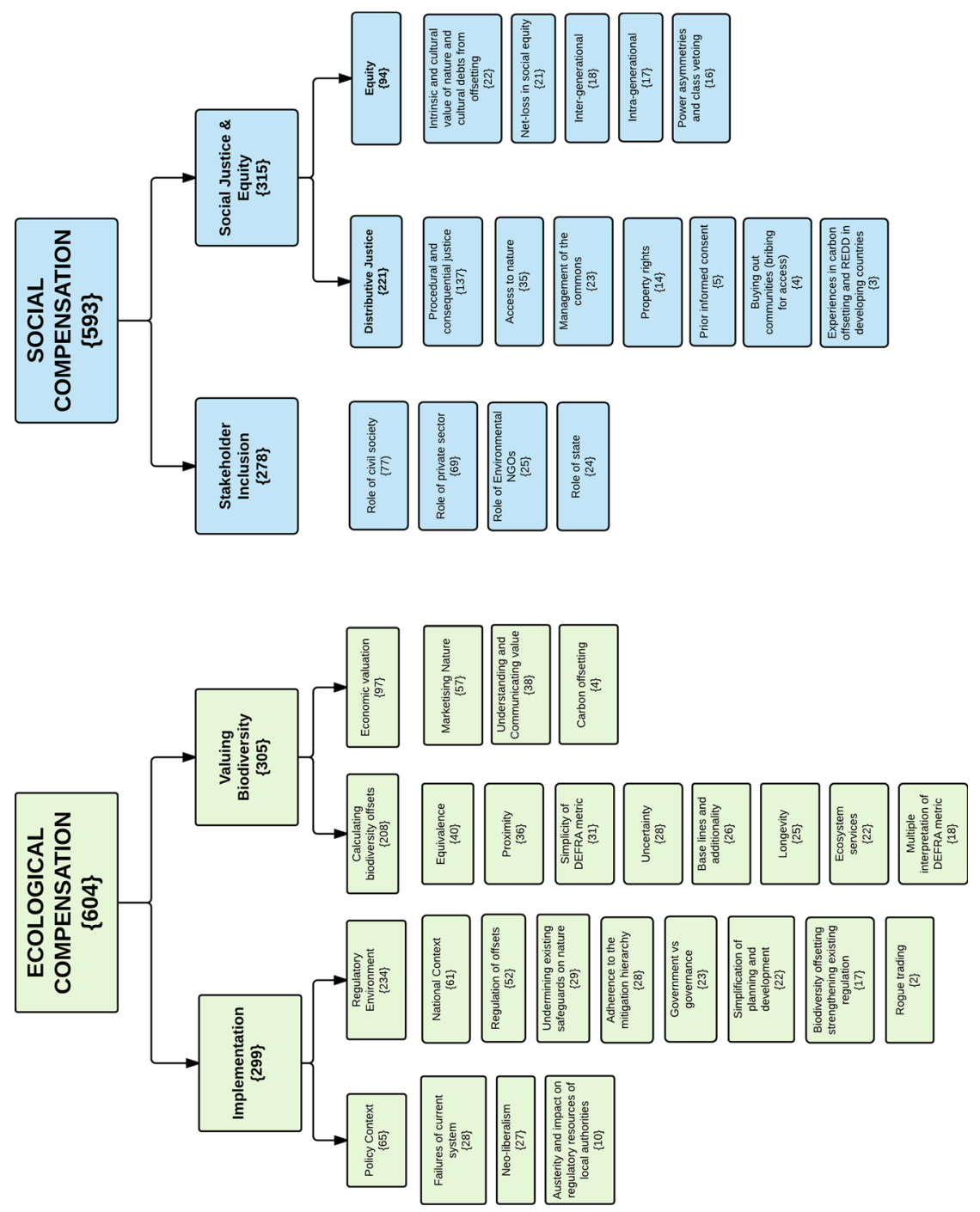

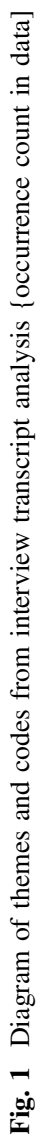


additionality $\{X=26\}$, longevity $\{X=25\}$, ecosystem services $\{X=22\}$ and multiple interpretation of the Defra metric $\{X=18\}$; and, economic valuation $\{X=97\}$ within the context of conservation, reflecting issues around marketising nature $\{X=57\}$, understanding and communicating value $\{X=38\}$ and the potential similarities between carbon offsetting and biodiversity offsetting in relation to rogue trading of environmental credits $\{X=4\}$.

\subsubsection{Implementation}

Respondents perceived lack of effective implementation, long-term monitoring and stakeholder participation as key barriers to achieving meaningful ecological compensation under Biodiversity Offsetting. The failure of the established legal compliance within the planning system to adequately protect biodiversity was a recurring issue. However, each stakeholder group identified different causes of policy failure. Local planning authority respondent 1 (LPA1), for example, attributed the failure to a lack of "forward planning for biodiversity", emphasising the need to go

... through the mitigation hierarchy at the pre-site allocation stage of the plan so that any sensitive sites are knocked out before they even get into the system for development.

Despite proponents of Biodiversity Offsetting viewing it as a last resort to mitigating biodiversity loss (BBOP 2013), academic researchers and environmental campaigners warned that such an instrument could promote a lackadaisical approach in earlier stages of site mitigation, and that improving avoidance of biodiversity impacts was central to reducing biodiversity loss. As Dempsey (2013) notes, the practice of screening sites helps in part to designate "no go" zones for business, but also helps appropriate "go zones" where developers can exercise less care over biodiversity issues.

According to offset brokers, the difficulty of implementing Biodiversity Offsetting is rooted in the problems developers face in navigating the labyrinth of regulations, jargon and bureaucratic procedures within the existing legal compliance to protect ecosystems and biodiversity:

They're [businesses] inherently grappling with quite complex and challenging issues... and have been bombarded with all this kind of stuff about green infrastructure and ecosystem services... all these kind of clunky phrases that they don't really understand. (EC1)

Meanwhile, there was disagreement over whether the implementation of Biodiversity Offsetting would strengthen or undermine existing legal regulations protecting the England's ecological network. Local planning authorities and offset brokers felt Biodiversity Offsetting would supplement existing legislation protecting habitats and species. However, environmental campaigners warned that Biodiversity Offsetting created

shades of grey, where there were not any before, over what can and cannot be developed on. (EC1)

Accordingly, EC2 cited a case where a previously rejected planning application was subsequently resubmitted, then granted, on the grounds that biodiversity loss could be offset elsewhere. Within this context, environmental campaigners regarded "no loss" and 
"no net loss" policy goals as fundamentally different, with the latter assuming a far weaker sustainability paradigm,

because you don't get an offset site without a site being destroyed. (EC2).

Conversely, academic researchers were concerned by the widening gap between policy rhetoric surrounding Biodiversity Offsetting and the practical and theoretical evidence base. AR1 expressed concern over poor design of the Biodiversity Offsetting pilot schemes in England:

I can see on the ground, the things on the ground implemented for mitigation, there has been no research done on them at all as to whether they actually work... We've spent a lot of money and it's not ecologically delivering at all.

Similarly, AR3 alluded to a gap between corporate commitments to deliver no net loss or net gain biodiversity targets - a growing phenomenon (Rainey et al. 2015) —and the necessary knowledge and experience required to fulfil these commitments. Moreover, they cited the transition from no net loss and net gain outcomes in offset projects as "difficult" and "...a lot of extra work" despite being perceived as "quite small [in terms of effort]" a view substantiated in Bull and Brownlie (2017).

There was also disagreement between stakeholders on the purported benefits Biodiversity Offsetting would deliver. While offset brokers envisaged biodiversity offsetting would produce net gains to biodiversity, academic researchers and environmental campaigners challenged the ecological evidence of a no net loss goal:

If you put the footprint of a building down, I'm not convinced you're getting No Net Loss, however great your mitigation is. (AR1)

AR2 noted that:

Just thinking you can kind of create a similar habitat somewhere else immediately de novo is pretty naïve... for anything more complex like a woodland or a salt marsh, then you are probably being very optimistic, even heroic, in thinking you can do it.

Despite disagreement over the effectiveness of Biodiversity Offsetting, several respondents felt the tool should be made mandatory for businesses and infrastructure development if the government insisted on implementing it. AR1 recalled practical issues with the voluntary nature of Biodiversity Offsetting in pilot studies, recounting:

people on the ground involved in the pilots were saying we're having real trouble getting developers to sign up to this.

However, AR3 challenged the high status of Biodiversity Offsetting has received in recent conservation discourse in the UK:

This is the mistake I think we have made in the UK so far. I think there has been this immediate leap towards Biodiversity Offsetting which is a controversial mechanism and isn't a proven mechanism yet, even though it has had some success in some parts of the world. The focus should be on no net loss and I think people are starting to realise that now.

Similarly, LPA3 agreed with the use of a metric in principle, but was "not convinced offsetting itself should be made mandatory".

Although Biodiversity Offsetting, as defined by Defra (2013a, b, p. 8) is expected to "observe the mitigation hierarchy", the (dis)incentives it creates for adherence to the 
mitigation hierarchy is unclear. Indeed, an assessment of the biodiversity offsetting pilot schemes in England by Baker et al. (2014, p. 64) found the use of the (Defra 2013a, b) metric for biodiversity "...tended to support the application of the mitigation hierarchy. However, within the pilot programme there were some applications where biodiversity offsetting was presented as a validated route for compensation and this may have undermined the hierarchy".

4.1.1.1 Regulatory environment With respect to regulation and enforcement, all stakeholders regarded the state as an important agent in mediating the implementation of Biodiversity Offsetting, although they recognised that ongoing budget cuts to government programmes and local authorities presented a major barrier to implementing, regulating and enforcing Biodiversity Offsetting. LPA 1 commented:

look at the planning system at the moment, look at the flaws in it. The real lack of ecologists. The biodiversity duty just not being properly considered at all within many local authorities. It's a resource problem, it's massive cuts within local authorities.

\section{Similarly, OB1 noted:}

we've got a local council whose budget is being stripped every single year and they own a lot of biodiversity spots that they have no money to manage, no money to do anything.

These observations bring into sharp focus the resource constraints to meaningfully implementing and monitoring biodiversity offsets. Conservation practitioners are increasingly expected to deliver adequate protection of ecosystems in an era of austerity and dwindling financial resources (Comerford et al. 2010; Corson 2010; McCarthy et al. 2012; Apostolopoulou et al. 2014). Within this environment, it is assumed that non-state actors and private investors will help bridge the shortfall between government provision of public goods and that which is socially optimal (Reid 2011; Young 2015). However, often this devolution of state power is not met with a fair reallocation of resources to local authorities to support alternative service delivery mechanisms. Complex issues such as redistributive justice and sustainability often become siloed, positioned in the problem space of organisations, outside the purview of broader governance processes (Furlong and Bakker 2010). In turn, communities increasingly become exposed to powerful corporate interests, weakening their ability to resist developments (McCarthy and Prudham 2004; Igoe and Brockington 2007).

Academic researchers and environmental campaigners viewed the increasing commitments of the private sector to conservation activities as an inadequate replacement for government provision of public goods. AR1 was concerned that money which is

meant to be additional to enhance areas or give additional land around SSSIs [Sites of Special Scientific Interest] might creep into what should be the statutory duty of government to be funding.

These sentiments were echoed by EC1, who was sceptical of the role of the private sector to meaningfully supplement government provision of public goods. EC1 expressed concern with:

the move towards a model, sadly in the UK where our environmental services or environmental management or the caretaking role is being potentially handed over to 
the private sector. [Private sector actors are] only going to provide money if they get something out of it and, you know, that's something we haven't quite grappled with as environmentalists:... that they don't do anything for free.

However, OB1 regarded the increasing role of private sector interest in conservation as a ... solution to corporate commitment on sustainable development [and] an absolute god-send for most local authorities [whose] budgets are being slashed.

\subsubsection{Valuing biodiversity}

In addition to concerns around implementation, an additional perceived barrier related to valuation of biodiversity and ecosystems $(X=305)$. We discerned two distinct discussions around valuation of ecosystems and biodiversity. First, economic valuation $(X=97)$, which considers whether biodiversity and ecosystems could, or indeed should, be monetised. Second, the calculation of biodiversity offsets $(X=208)$, in which environmental campaigners, academic researchers and local planning authorities highlighted several issues with the proposed method of evaluating biodiversity loss and compensation.

4.1.2.1 Economic valuation The notion of monetising and marketing biodiversity offsets was criticised by academic researchers and environmental campaigners. A key theme in the academic researchers' critique was the limitations of using valuation as a tool for informing environmental management. AR1 suggested habitats that are "ecologically irreplaceable" should not be given an economic value since "they can't rebuild them in any reasonable time scale". AR1 also emphasised a more intangible imperative for protecting the environment, commenting:

If we get into a complete viewpoint where everything we can put a monetary value on it and all into economic terms and not consider our moral and almost spiritual need for nature then that's quite a depauperate way of viewing nature. So I think you can use those tools with caution. But you need to step outside that and recognise both the irreplaceable aspects of nature and moral, intrinsic aspects of nature you can't value.

Environmental campaigners offered a more critical perspective on this issue:

It's a really sensible tool if we're in an ideal, fluffy bunny world where everyone is out for the best, but unfortunately that isn't the way things are run... it's going to become a tool that enables the speeding through of development. (EC2)

Several respondents (AR1, EC1, OB1, OB2, OC3) acknowledged economic valuation of ecosystems and biodiversity is important for agenda building. Respondents agreed such exercises helped to raise awareness of the non-market benefits derived from nature. OB1 also said environmental valuation was an invaluable communication tool in their work:

... using numbers to translate and communicate biodiversity to the business people has really transformed my work... it becomes so much more powerful in terms of getting them [businesses] engaged...

However, all stakeholders agreed a Biodiversity Offsetting "market" demanded tight, independent, regulation. $\mathrm{AR} 1, \mathrm{EC} 1, \mathrm{OB} 2, \mathrm{OB} 3$ cited the operational failure of carbon 
offsetting, and the proliferation of "rogue traders" offering carbon credits, as clear justification for certification of biodiversity offsets. AR1 warned that, without appropriate rules, checks and balances, Biodiversity Offsetting could become “... a complete license to trash". Indeed, in the context of poor governance, several people have argued Biodiversity Offsetting would promote rent-seeking behaviour, whereby individuals use their property assets to profit from offset provision without creating "new" habitats, leading to a net loss in biodiversity (Walker et al. 2009; Bull et al. 2013). EC3 went so far as to condemn the overall role of Biodiversity Offsetting as a tool for conservation, suggesting it offers developers "entitlements" to destroy nature, whereby the availability to purchase biodiversity credits assigns newfound rights to do so. Here, metrics of ecological value support the delineation of nature by usable and unusable space (Dempsey 2013). Meanwhile, LPA respondents and AR1 raised concerns said that in their experience landowners show little interest in or demand for becoming "offset providers" - actors who earmark their land for wildlife conservation to provide offset credits to nearby developments (Environment Bank Ltd 2014). AR1 and LPA2 suggested landowners worked in short-term economic cycles of 3-5 years, so were reluctant to commit to permanent land use stipulated by $50-100$-year Biodiversity Offsetting agreements. They also suggested farmers a major focus group of Biodiversity Offsetting may be averse to allocating land for non-agricultural use for cultural reasons (e.g. having a productivist mindset). This view is substantiated by the England's National Farmers' Union (2013) consultation response to Biodiversity Offsetting.

\subsubsection{Calculating biodiversity offsets We detected divergence in respondents' attitudes} towards the measurement of biodiversity credits. OB1 believed the use of the current planning system provided local authorities and businesses with "no way of really quantifying and knowing how good their work is". OB1 also suggested the Defra metric for measuring biodiversity units would address inconsistencies within the compensation process by tightening up the mitigation hierarchy and "casting a spotlight on it". This standpoint was shared by LPA2, whose practical experience managing Biodiversity Offsetting pilot schemes was mostly positive.

OB2 expressed similar confidence in the proposed Biodiversity Offsetting framework, acknowledging that Biodiversity Offsetting is "not a perfect system" but "it is certainly better than what is being delivered at the moment". OB2 went on to rationalise the use of Biodiversity Offsetting on the grounds that the urgency of biodiversity loss requires immediate remedy:

We need to do something and we need to do it now and strive for perfection in the future.

The remaining stakeholders-the environmental campaigners, academic researchers and LPA1-were more critical of the measurement procedures involved in calculating biodiversity units, viewing them as shortsighted and highlighting systemic flaws in the design and implementation of the proposed (Defra 2013b) metric for Biodiversity Offsetting in England.

AR2 distinguished between Biodiversity Offsetting as "a generic process" and Biodiversity Offsetting as proposed by the government green paper (Defra 2013b). They were confident that Biodiversity Offsetting "as a generic process" could certainly afford species greater protection, but despaired of the method proposed in the green paper:

Biodiversity Offsetting à la green paper is probably fundamentally flawed in any respect and may only help the planners. [It is] a dog's breakfast of ill-defined stuff... 
a bit woolly and not very well put together and really talks about individual species and not ecological processes.

Similarly, LPA1 regarded the proposed habitat metric as "too simplistic and inadequate for what it should do". AR3 made several observations on the weaknesses of the Defra metric. First they proposed a shift away from an "all-singing, all-dancing metric that can do all different types of habitats" and restricting it to certain habitat types where it has been shown to work. Second, they highlighted "baselines and counterfactuals" as a blind-spot within the existing metric and recommended greater recognition of "background trends, a baseline, and counterfactuals", to demonstrate "proactive habitat creation". Lastly, they criticised the lack of empirical evidence used to determine multipliers for compensating ecological value between a development site and offset site which they perceived to be "plucked out of the air".

Referring to the calculation of biodiversity units attained under the Defra metric, AR1 noted:

... if people start thinking that this is a highly developed science then there is a risk... these numbers are broad representatives to try to do better than we do at the moment, but compared to some other schemes they are quite laughable in their simplicity.

Overall, local planning authorities, academic researchers and environmental campaigners felt that Biodiversity Offsetting according to the green paper would fail to achieve either social or ecological compensation, by overlooking issues of proximity, the irreplaceability of nature, ecosystem services, longevity and discounting in ecological compensation.

\subsection{Social compensation}

Analysis of stakeholder responses highlighted social compensation as an equally significant component of Biodiversity Offsetting to ecological compensation, denoted by the strong recurrence of two main themes in the responses: stakeholder inclusion $(X=278)$ and social justice and equity $(X=315)$. Stakeholder inclusion concerned the level of involvement of different conservation stakeholders in the design, development and delivery of Biodiversity Offsetting, how this was shaped by the prevailing expert/nonexpert conservation paradigm, and the role of affected communities in defining the conditions of an offset and involvement in its implementation. Social justice and equity represented issues of community-related compensation associated with Biodiversity Offsetting: procedural and consequential justice $(X=137)$; access to nature $(X=35)$; intergenerational equity $(X=18)$; intra-generational equity $(X=17)$; and property rights $(X=14)$, and how these were treated within the proposed Defra metric.

\subsubsection{Stakeholder inclusion}

Respondents identified stakeholder participation as an integral component to the successful design and implementation of any conservation intervention. Offset Broker 1 emphasised the propensity of Biodiversity Offsetting to build cohesive relationships between companies and wildlife organisations, by involving conservation groups in implementing biodiversity strategies. Yet environmental campaigners felt the alliance of businesses and wildlife organisations within the design and implementation of Biodiversity Offsetting was 
being achieved at the expense of marginalising those local people most affected by development and biodiversity loss:

my biggest concern throughout this whole process is people haven't been consulted, civil society, has knew nothing about it... communities went to those NGOs expecting them to fight to protect local green space, only to then find out they were part of it and they are on their own. (EC2)

Environmental campaigner 1 argued "communities are often the experts of the landscape" and hold rich information regarding the management needs of their local environment, though felt this was being ignored by large wildlife organisations:

I'm always told by charities "oh people don't care". I think that's rubbish, people do care and that's why there is always a campaign kicking off when somebody wants to cut down a tree. It's just they are not given a chance to express that other than when their landscape is threatened. So get them involved at the decision-making stage. Get them involved way before the decision making stage.

Although academic researchers acknowledged the importance of wider stakeholder participation, they highlighted significant barriers to social inclusion within the design and implementation of Biodiversity Offsetting. They asserted that councils lacked the financial resources to facilitate costly consultation processes (stakeholder forums and referendums) and were instead forced to operate within a consequentialist mindset: preoccupied by policy outcomes, not processes. Academic researchers emphasised a commensurate dearth of experience and knowledge within local planning to meaningfully include civil society within the formal apparatus of government policy-making. Instead, AR2 noted, power dynamics within government policy-making resulted in powerful individuals monopolising the issue-attention cycle of local authorities, eclipsing the needs of other stakeholders. However, LPA1 disputed the importance of wider stakeholder participation, on the grounds that affected communities "don't have any ecological expertise". The limited extent to which affected stakeholders within Biodiversity Offsetting projects inform their design, implementation, and evaluation is likely to have a major implications for social compensation. Indeed, meaningful stakeholder engagement in conservation interventions can help to identify and address conflicts between different interest groups by finding overlap between outcomes (Redpath et al. 2013; Reed 2008).

\subsubsection{Social equity and justice}

Several respondents raised concerns around the treatment of social equity and justice within the current apparatus of Biodiversity Offsetting. The majority of stakeholders agreed there was a poor articulation of equity issues within the existing Biodiversity Offsetting guidelines in England. AR2 emphasised that achieving no net loss in ecological value did not necessarily infer no net loss in distributive justice:

So you've got the habitat and, there is no net loss [in ecological value], but the benefits are lost to those individual people, that's an equity issue, a social-justice issue the green paper fails to deal with.

LPA2 felt the omission of equity concerns from the formal Biodiversity Offsetting process would impose "cultural debts" on current and future generations, in the form of a loss in access to environmental amenities which possess significant cultural, educational and historical value to local people. Within the context of social compensation, EC1 
emphasised the importance of establishing free prior informed consent with communities in which development was occurring, suggesting that if this criterion is not satisfied:

We need to be humble enough to admit that that is not an offset; it's not even a compensation.

EC2 agreed that failure to consult those affected by Biodiversity Offsetting undermined the agency of affected communities:

It's the responsibility of the democratic structure that we are living in. If things are going to be changed in order to disable the rights of people in the community to have a say over what happens with their landscape, then that's a cut in democracy as far as I'm concerned.

Notably, EC1 suggested that power dynamics would govern the degree of social compensation resulting from Biodiversity Offsetting and concluded that a large landowner would invariably have more influence over the planning process than the "people that have the council housing on the outskirts". AR2 also suggested that poorer communities were more likely

to accept remuneration or buy-offs than perhaps richer communities which would have the luxury of saying no.

Similarly, AR3 expressed strong support for social compensation of affected communities within the framework of Biodiversity Offsetting and the mitigation hierarchy, highlighting the importance of access to nature in England compared with other nations, commenting:

We are a small island which is heavily developed with lots and lots of people living very close to each other. I think access to nature is a huge part of the value of the remaining biodiversity. So, I would say, actually yes, it is crucial that Biodiversity Offsetting incorporates considerations of affected communities and access to nature for those affected communities.

AR3 also noted the omission of social compensation within the Defra metric and suggested its introduction via measurement of ecosystem service provision in the delivery of an offset, concluding that "utility value and access to nature or something like that could be made part of the Defra process without too much difficulty". AR3 went on to outline how a more holistic approach to compensation might deliver co-benefits for local communities as well as safeguarding natural habitats from development. The social-ecological compensation attached would make it prohibitively expensive to offset biodiversity impact retrospectively, driving “... the developers to look at more minimisation or avoidance measures-which is kind of the point".

EC3 cited the case of Germany's infrastructure planning law whereby if you "destroy rights of way, you have to re-establish them", suggesting this as a useful requirement for ensuring commensurate access to nature between a development site and offset site.

Despite recognising the distinct importance of public access to nature within the UK, academic researchers and offset brokers highlighted a potential conflict between, on the one hand providing a prosperous environment for biodiversity and ecosystems to thrive, and on the other providing a suitable environment for access to green space. To this end, offset brokers were less inclined to support the inclusion of social compensation within the Defra metric, suggesting that such issues are, and would continue to be, dealt with implicitly during the scoping and application of offsets with local authorities and via other mechanisms surrounding green infrastructure. 


\section{Discussion and conclusions}

This article examines stakeholder perspectives towards the use of Biodiversity Offsetting as a tool for conservation practice in England. Responses highlighted a broad landscape of considerations surrounding the theoretical, practical and regulatory dimensions of the Defra metric (Defra 2013b) and the 2013 UK pilot projects. Foremost, this analysis provides further evidence that the requirements for achieving no net loss are poorly defined in conservation practice in England (Bull et al. 2013; Sullivan and Hannis 2015). The highly normative definitions of no net loss transcend simple ecological compensation criteria. Instead, our findings redress the notion of "loss" within this context along both ecological and sociocultural lines. This finding is symptomatic of the broader disjuncture between scholars and practitioners around defining what conservation actually means (Sandbrook 2015).

Conceptualising the type of compensation involved in an offset remains poorly investigated, yet has significant implications for the compensation of biodiversity loss and communities dependent on nature (Bull et al. 2013; Gonçalves et al. 2015). At present 'no net loss' is a misnomer for the actual costs associated with biodiversity loss (Carver 2015; Sullivan and Hannis 2015). Our interviews with conservation stakeholders (academic researchers, offset brokers, environmental campaigners and local planning authorities) highlighted ecological compensation and social compensation as equally important. However, at present, social compensation represents a major blind-spot within the Defra offsetting metric, as illustrated in this study and as noted in an appraisal of the Biodiversity Offsetting projects in England:

The restricted range of ecosystem services valued also meant some of the potentially larger social and wellbeing benefits of access to nature were not fully considered.

(Defra 2013a)

Ostensibly, the findings of this article would suggest a greater mainstreaming of socioecological issues associated within biodiversity loss to be a sensible improvement to the Defra metric, which largely only considers habitat type and quality in compensating biodiversity loss. Indeed, as AR3 suggested, formal requirements to compensate community losses, such as access to nature, as part of the Defra metric, could create a more robust safeguard for the protection of an ecological site in the first instance. Equally, incorporating wider ecological parameters into the assessment and implementation of Biodiversity Offsetting to bolster ecological compensation (around proximity, equivalence, ecosystem processes and longevity) would implicitly factor issues related to distributive and procedural justice into the offsetting equation, resulting in greater social compensation. At present, some of these values are dealt with using multipliers, where gains are scaled to be greater than losses; however, as Bull et al. (2017) notes, there may be cases in which such measures are incapable of meaningfully compensating for biodiversity loss, particularly where ethical and sociocultural values are concerned. Without due attention to social compensation, biodiversity offsetting could transform sites of previous common heritage into gated ecological offset sites (Sullivan 2012).

On closer inspection, however, extending the framework of no net loss to recognise and accommodate additional ecological parameters and social equity concerns in Biodiversity Offsetting is neither a workable solution nor a desirable outcome for conservation. Indeed, the Defra metric, as with other systems of classification in market-based conservation, captures only the "nature that capital can see" (Robertson 2006a, b). Consideration of, and 
compensation for complex issues linked to social and ecological compensation of biodiversity loss appear incompatible with the goal of bundling nature into "biodiversity units". A key element to the consolidation of the value of biodiversity within this context is the manner in which "those implicated in the accumulation of value are also those implicated in the attribution of value itself" (Fairhead et al. 2012). To this end, it is important to critically reflect on what is being defined as the value of biodiversity, and by whom (Maron et al. 2016). Even if attempts were made to integrate such issues, to appease local communities and the scientific community, they would invariably involve conflating, abstracting and equating complex issues within the assessment of biodiversity loss, placing them at greater risk of being misappropriated, traded off or crudely compensated, rather than legitimised. Supposing the recommendations of respondents were meaningfully reflected in conservation practice in England, the instrument(s) used to safeguard ecosystems, biodiversity and the nature-society relationship would be almost unrecognisable from Biodiversity Offsetting in its current, or improved form.

Biodiversity Offsetting is evolving in the vanguard of an international appetite for accounting-driven conservation, in which the use of indicators to measure trends in biodiversity loss can be seen across several policy agendas (Benabou 2014). The recently adopted UN Sustainable Development Goals explicitly use no net loss style indicators to monitor trends in biodiversity; for example, Target 15.2 on sustainable forest management employs an indicator which monitors "Net permanent forest loss" (UN Economic and Social Council 2016). The direction of the EU's Biodiversity Strategy over the last 20 years also illustrates a shift in the goal-post of conservation from no loss to no net loss (European Commission 1993, 2006, 2012). There are at least 56 countries which are estimated to have laws or policies requiring biodiversity offsets or some form of compensatory conservation, encompassing over 100 schemes (OECD 2016). Within these different contexts in which biodiversity offsetting is gaining traction, it is important to observe whether the increasing classification and measurement of biodiversity will reduce or strengthen accountability for biodiversity loss and associated responsibilities for its compensation (Tregidga 2013). How will Biodiversity Offsetting shape 'red lines' for the protection of ecosystems and biodiversity, and who are the winners and losers in each case? In order to understand this quantitative assessment of conservation interventions needs to be complemented with qualitative evaluation and ground-truthing, drawing on practitioner and stakeholder surveys in order to identify and resolve issues associated with conservation programmes (Tittensor et al. 2014; Tallis and Lubchenco 2014). Such form of inquiry, as undertaken in this study, and by others within this context (Apostolopoulou 2016; Carver 2015; Carver and Sullivan 2017; Sullivan and Hannis 2015), provide a crucial step in helping to unpack the underlying decisions, preferences and trade-offs involved in conservation activities, which are at risk of being veiled within "units of biodiversity" via the use of instruments such as Biodiversity Offsetting (Spash 2015).

In taking forward this agenda, we identify three immediate research gaps that require further investigation, set out below.

First, we recommend a similar qualitative inquiry into the attitudes of landowners to allocating land for offset sites, to help verify the mechanisms through which biodiversity offsets might operate in England (Lawton et al. 2010). It has been widely reported that farmers have productivist or traditionalist mindsets and see land as the preserve of agricultural production (Howley 2015; Howley et al. 2015; McCracken et al. 2015).

Second, building on the UK Law Commission Conservation Covenants investigation (UK Law Commission 2014), we identify a clear need for research into the development of a uniform system of protecting offset sites via conservation covenants and the challenges 
presented by the seemingly disparate application of approaches to offsetting between different local authorities.

Third, future work around siting controversies needs to view the process of "accumulation by dispossession" in relation to the conversion of public commons to private land, between a development site and an offset site, but also as a process of dispossession at the offset site, particularly where poor property rights regimes give rise to land grabbing for so-called Fortress Conservation (Büscher 2016; Hackett 2016).

The analysis in this article offers a rationale to reconnect the offsetting debate with a deeper understanding of the diverse socio-ecological values associated with biodiversity loss, which is long overdue. This message is also salient within the burgeoning international application of Biodiversity Offsetting, where treatment of social equity and justice issues remain at the peripheries of scholarship and practice.

\section{Supplementary information}

Full transcripts from all interviews can be found online here: dataverse.harvard.edu/ dataverse.xhtml?alias=biodiversityoffsetting.

Acknowledgements The authors are very grateful to all the participants in the study for their unique insight on the topic of Biodiversity Offsetting. Thanks is also owed to Dr Simon Croft and Dr Sarah West of the Stockholm Environment Institute for their constructive feedback on the initial draft of the manuscript. We also acknowledge the useful comments received from the anonymous reviewers which helped to improve the article.

Open Access This article is distributed under the terms of the Creative Commons Attribution 4.0 International License (http://creativecommons.org/licenses/by/4.0/), which permits unrestricted use, distribution, and reproduction in any medium, provided you give appropriate credit to the original author(s) and the source, provide a link to the Creative Commons license, and indicate if changes were made.

\section{Appendix 1: Respondents in study}

\begin{tabular}{|c|c|c|}
\hline Position & Group & Relevant expertise \\
\hline Professor of ecology & $\begin{array}{l}\text { Academic } \\
\text { researchers }\end{array}$ & $\begin{array}{l}\text { Provided input to UK Biodiversity } \\
\text { Offsetting consultation. Experience } \\
\text { working extensively on the relationships } \\
\text { between biodiversity, and ecosystem } \\
\text { services functioning, and conservation } \\
\text { policy }\end{array}$ \\
\hline Engagement officer and researcher & $\begin{array}{l}\text { Academic } \\
\text { researchers }\end{array}$ & $\begin{array}{l}\text { Conducted research on behalf of the UK } \\
\text { Government on the merits and limitations } \\
\text { of Biodiversity Offsetting }\end{array}$ \\
\hline Lecturer on biodiversity & $\begin{array}{l}\text { Academic } \\
\text { researchers }\end{array}$ & $\begin{array}{l}\text { Expert in restorative ecology and has } \\
\text { advised widely on the topic of } \\
\text { Biodiversity Offsetting }\end{array}$ \\
\hline $\begin{array}{l}\text { Director of environmental campaigning } \\
\text { organisation }\end{array}$ & $\begin{array}{l}\text { Environmental } \\
\text { campaigners }\end{array}$ & $\begin{array}{l}\text { Involvement in campaigning on } \\
\text { Biodiversity Offsetting and sell-off of } \\
\text { UK Forest Estate }\end{array}$ \\
\hline $\begin{array}{l}\text { Researcher and campaigner at major } \\
\text { European environmental NGO }\end{array}$ & $\begin{array}{c}\text { Environmental } \\
\text { campaigners }\end{array}$ & $\begin{array}{l}\text { Engagement with research and } \\
\text { campaigning on Biodiversity Offsetting }\end{array}$ \\
\hline
\end{tabular}




\begin{tabular}{|c|c|c|}
\hline Position & Group & Relevant expertise \\
\hline $\begin{array}{l}\text { Leader in International biodiversity Policy } \\
\text { at major global environmental NGO }\end{array}$ & $\begin{array}{l}\text { Environmental } \\
\text { campaigners }\end{array}$ & $\begin{array}{l}\text { Coordinated response to EU No Net Loss } \\
\text { consultation and has knowledge of } \\
\text { implementation of Biodiversity } \\
\text { Offsetting in France, Germany and the } \\
\text { UK }\end{array}$ \\
\hline $\begin{array}{l}\text { Principal ecologist from, local authority in } \\
\text { Warwickshire County Council }\end{array}$ & $\begin{array}{l}\text { Local planning } \\
\text { authorities }\end{array}$ & $\begin{array}{l}\text { Responsible for implementing Biodiversity } \\
\text { Offsetting pilot in Warwickshire }\end{array}$ \\
\hline $\begin{array}{l}\text { Senior practitioner in nature conservation, } \\
\text { Nottinghamshire County Council }\end{array}$ & $\begin{array}{l}\text { Local planning } \\
\text { authorities }\end{array}$ & $\begin{array}{l}\text { Responsible for implementing biodiversity } \\
\text { pilot in Nottinghamshire }\end{array}$ \\
\hline $\begin{array}{l}\text { Senior practitioner in nature conservation, } \\
\text { Devonshire County Council }\end{array}$ & $\begin{array}{l}\text { Local planning } \\
\text { authorities }\end{array}$ & $\begin{array}{l}\text { Responsible for implementing biodiversity } \\
\text { pilot in Devon }\end{array}$ \\
\hline $\begin{array}{l}\text { National Programme manager in private } \\
\text { sector organisation who has dealt with } \\
\text { brokering deals between developers with } \\
\text { landowners to achieve offsets }\end{array}$ & Offset brokers & $\begin{array}{l}\text { Involved in Essex Biodiversity Ofsetting } \\
\text { pilot. Previous experience as an offset } \\
\text { broker in the Australian BushBroker } \\
\text { scheme and extensive experience scoping } \\
\text { receptor sites for Biodiversity Offsetting }\end{array}$ \\
\hline $\begin{array}{l}\text { Project manager in private sector } \\
\text { organisation who has dealt with } \\
\text { brokering deals between developers with } \\
\text { landowners to achieve offsets }\end{array}$ & Offset brokers & $\begin{array}{l}\text { Involved in Essex Biodiversity Offsetting } \\
\text { pilot and liaising with planning teams at } \\
\text { the county and borough planning } \\
\text { authorities to calculate credit } \\
\text { requirements of development proposals }\end{array}$ \\
\hline $\begin{array}{l}\text { Biodiversity leader at major planning, } \\
\text { engineering and construction } \\
\text { management organisation }\end{array}$ & Offset brokers & $\begin{array}{l}\text { Experience of scoping Biodiversity } \\
\text { Offsetting projects in the UK }\end{array}$ \\
\hline
\end{tabular}

\section{Appendix 2: Interview guide}

\section{Mainstreaming Biodiversity Offsetting into the planning system}

Are biodiversity offsets likely to lead to tighter or less stringent regulations around infrastructure projects?

Based on your experience, do you think Biodiversity Offsetting should be made mandatory for infrastructure projects?

What is your opinion regarding the adoption of a 'no net loss' policy goal?

\section{Equity considerations}

When undertaking biodiversity offsets, do you think compensating affected communities is always necessary and practical?

To what extent do you think the benefits derived from ecosystems are amenable to economic valuation?

\section{Agenda-building capacity}

What do you think the role of market-based instruments is in reversing biodiversity loss?

What affect do you think the increasing emphasis on market-based instruments for reversing biodiversity loss will have on conservation objectives? 
What role does Biodiversity Offsetting play in realising the goals of the Natura 2000 network and increasing conservation in UK and EU?

\section{Biodiversity Offsetting in practice}

Is the mitigation hierarchy a well-recognised framework for infrastructure development?

What opportunities are posed by private sector provision of biodiversity offsetting?

What risks are posed by private sector provision of biodiversity offsetting?

What factors should determine the location of an offset with respect to an affected community?

\section{References}

Albon, S. D., Turner, R. K., Watson, R., Anger, A., \& UNEP World Conservation Monitoring Centre. (2014). UK national ecosystem assessment follow-on: Synthesis of the key findings. Cambridge: UNEP World Conservation Monitoring Centre.

Ambrose, R. F. (2000). Wetland mitigation in the United States: Assessing the success of mitigation policies. Wetlands, 19, 1-27.

Apostolopoulou, E. (2016). Biodiversity offsetting in England: Governance rescaling, socio-spatial injustices, and the neoliberalization of nature. Web Ecology, 16, 67-71. doi:10.5194/we-16-67-2016.

Apostolopoulou, E., \& Adams, W. M. (2017). Biodiversity offsetting and conservation: Reframing nature to save it. Oryx, 51, 23-31. doi:10.1017/S0030605315000782.

Apostolopoulou, E., Bormpoudakis, D., Paloniemi, R., Cent, J., Grodzińska-Jurczak, M., Pietrzyk-Kaszyńska, A., et al. (2014). Governance rescaling and the neoliberalization of nature: The case of biodiversity conservation in four EU countries. International Journal of Sustainable Development and World Ecology, 21(6), 481-494. doi:10.1080/13504509.2014.979904.

Baker, J., Sheate, W. R., Benett, T., Payne, D., Tucker, G., White, O., et al. (2014). WC1051: Evaluation of the Biodiversity Offsetting pilot programme. London: Department for Environment, Food and Rural Affairs, Colingwood Environmental Planning Ltd., The Institute for European Environmental Policy.

Baker, J., Sheate, W. R., Papadopoulou, L., Bennett, T., Payne, D., \& Bull, J. (2013). Indicative costs of current compensation arrangements for biodiversity loss: Illustrative case studies (evaluation of the biodiversity offsetting pilot phase no. report on task 4). Defra project code: WC 1051. Collingwood Environmental Planning Limited; The Institute for European Environmental Policy (IEEP).

Balmford, A. (2002). Economic reasons for conserving wild nature. Science, 297(5583), 950-953. doi:10. $1126 /$ science. 1073947.

Barrett, C. B., Brandon, K., Gibson, C., \& Gjertsen, H. (2001). Conserving tropical biodiversity amid weak institutions. BioScience, 51(6), 497. doi:10.1641/0006-3568(2001)051[0497:CTBAWI]2.0.CO;2.

BBOP. (2013). To no net loss and beyond: An overview of the business and biodiversity offsets programme. Washington D.C.: Forest Trends Association.

Benabou, S. (2014). Making up for lost nature? A critical review of the international development of voluntary biodiversity offsets. Environment and Society. doi:10.3167/ares.2014.050107.

Berkes, F. (2007). Community-based conservation in a globalized world. Proceedings of the National Academy of Sciences, 104(39), 15188-15193. doi:10.1073/pnas.0702098104.

Braun, B., \& Castree, N. (Eds.). (1998). Remaking reality: Nature at the millenium. London, New York: Routledge.

Brooks, J. S., Waylen, K. A., \& Borgerhoff Mulder, M. (2012). How national context, project design, and local community characteristics influence success in community-based conservation projects. Proceedings of National Academy of Sciences, 109, 21265-21270. doi:10.1073/pnas.1207141110.

Bryman, A., Burgess, R. G. (Eds.). (1994). Analyzing qualitative data. London, New York: Routledge.

Bull, J. W., \& Brownlie, S. (2017). The transition from no net loss to a net gain of biodiversity is far from trivial. Oryx, 51, 53-59. doi:10.1017/S0030605315000861.

Bull, J. W., Lloyd, S. P., Strange, N. (2017). Implementation gap between the theory and practice of biodiversity offset multipliers. Conservation Letters. doi:10.1111/conl.12335.

Bull, J. W., Suttle, K. B., Gordon, A., Singh, N. J., \& Milner-Gulland, E. J. (2013). Biodiversity offsets in theory and practice. Oryx, 47(3), 369-380. doi:10.1017/S003060531200172X. 
Burns, R., Eaton, M. A., \& Gregory, M. D. (2013). The state of nature in the UK and its overseas territories. London: State of Nature partnership.

Büscher, B. (2016). Reassessing fortress conservation? New media and the politics of distinction in Kruger National Park. Annals of the American Association of Geographers, 106(1), 114-129. doi:10.1080/ 00045608.2015.1095061.

Carver, L. (2015). Measuring the value of what? An ethnographic account of the transformation of "Nature" under the DEFRA biodiversity offsetting metric, LCSV working paper series no. 11. Leverhulme Centre for the Study of Value.

Carver, L., \& Sullivan, S. (2017). How economic contexts shape calculations of "yield" in biodiversity offsetting. Conservation Biology. doi:10.1111/cobi.12917.

Cavanagh, C., \& Benjaminsen, T. A. (2014). Virtual nature, violent accumulation: The 'spectacular failure' of carbon offsetting at a Ugandan National Park. Geoforum, 56, 55-65. doi:10.1016/j.geoforum.2014. 06.013.

Comerford, E., Molloy, D., \& Morling, P. (2010). Financing nature in an age of austerity. London: Royal Society for the Protection of Birds. https://www.rspb.org.uk/Images/Financingnature_tcm9-262166. pdf.

Corbera, E., \& Brown, K. (2010). Offsetting benefits? Analyzing access to forest carbon. Environment and Planning A, 42(7), 1739-1761. doi:10.1068/a42437.

Corson, C. (2010). Shifting environmental governance in a neoliberal world: US AID for conservation. Antipode, 42(3), 576-602. doi:10.1111/j.1467-8330.2010.00764.x.

Defra (2013a). Biodiversity offsetting: Impact assessment. https://consult.defra.gov.uk/biodiversity/ biodiversity_offsetting/supporting_documents/20130829Biodiversity\%20offsetting\%20IA.pdf.

Defra (2013b). Biodiversity offsetting in England. Green paper. London: Department for Environment, Food and Rural Affairs.

Dey, I. (1999). Grounding grounded theory: Guidelines for qualitative inquiry. Academic Press: San Diego.

Dempsey, J. (2013). Biodiversity loss as material risk: Tracking the changing meanings and materialities of biodiversity conservation. Geoforum, 45, 41-51. doi:10.1016/j.geoforum.2012.04.002.

Dempsey, J., \& Robertson, M. M. (2012). Ecosystem services: Tensions, impurities, and points of engagement within neoliberalism. Progress in Human Geography. doi:10.1177/0309132512437076.

Dempsey, J., \& Suarez, D. C. (2016). Arrested development? The promises and paradoxes of 'Selling Nature to Save It'. Annals of the American Association of Geographers. doi:10.1080/24694452.2016.1140018.

eftec, et al. (2010). The use of market-based instruments for biodiversity protection-The case of habitat banking-Technical report. Brussels: European Commission.

Environment Bank Ltd (2014). The environmental markets exchange. http://www.environmentbank.com/ environmental-markets-exchange.php.

Environmental Audit Committee. (2013). Biodiversity Offsetting: Sixth report of session 2013-14. London: Stationery Office.

EPA. (2015). Wetland compensatory mitigation. United States Environmental Protection Agency. https:// www.epa.gov/sites/production/files/2015-08/documents/compensatory_mitigation_factsheet.pdf.

European Commission (1993). Towards sustainability. Brussels: European Commission. http://ec.europa.eu/ environment/archives/env-act5/pdf/5eap.pdf.

European Commission (2006). Halting the loss of biodiversity by 2010 - and Beyond. Brussels. http://eurlex.europa.eu/legal-content/EN/TXT/PDF/?uri=CELEX:52006DC0216\&from=EN.

European Commission. (2008). Natura 2000: Protecting Europe's biodiversity. Brussels. doi:10.2779/45963.

European Commission (2012). Living well, within the limits of our planet: Proposal for a general union environment action programme. Brussels, Belgium. http://ec.europa.eu/environment/newprg/pdf/ 7EAP_Proposal/en.pdf.

Evans, D. M., Altwegg, R., Garner, T. W. J., Gompper, M. E., Gordon, I. J., Johnson, J. A., et al. (2015). Biodiversity offsetting: What are the challenges, opportunities and research priorities for animal conservation?: Biodiversity offsetting. Animal Conservation, 18(1), 1-3. doi:10.1111/acv.12173.

Fairhead, J., Leach, M., \& Scoones, I. (2012). Green grabbing: A new appropriation of nature? Journal of Peasant Studies, 39(2), 237-261. doi:10.1080/03066150.2012.671770.

Fuller, R. A., Irvine, K. N., Devine-Wright, P., Warren, P. H., \& Gaston, K. J. (2007). Psychological benefits of greenspace increase with biodiversity. Biology Letters, 3(4), 390-394. doi:10.1098/rsbl.2007.0149.

Furlong, K., \& Bakker, K. (2010). The contradictions in "alternative" service delivery: Governance, business models, and sustainability in municipal water supply. Environment and Planning C: Government and Policy, 28(2), 349-368. doi:10.1068/c09122.

Given, L. M. (Ed.). (2008). The Sage encyclopedia of qualitative research methods. Sage Publications: Los Angeles. 
Glaser, B. G., \& Strauss, A. L. (2009). The discovery of grounded theory: Strategies for qualitative research. New Brunswick, NJ: Aldine.

Gómez-Baggethun, E., de Groot, R., Lomas, P. L., \& Montes, C. (2010). The history of ecosystem services in economic theory and practice: From early notions to markets and payment schemes. Ecological Economics, 69(6), 1209-1218. doi:10.1016/j.ecolecon.2009.11.007.

Gonçalves, B., Marques, A., Soares, A. M. V. D. M., \& Pereira, H. M. (2015). Biodiversity offsets: From current challenges to harmonized metrics. Current Opinion in Environmental Sustainability, 14, 61-67. doi:10.1016/j.cosust.2015.03.008.

Halaweh, M. (2012) A case study of using grounded theory-based technique for system requirements analysis. Journal of Information Systems and Technology Management, 9(1), 23-38.

Hackett, R. (2016). "Shell games", displacement and the reordering of boreal landscapes in Alberta, Canada. Area, 48(2), 153-160. doi:10.1111/area.12158.

Hannis, M., \& Sullivan, S. (2012). Offsetting nature?: Habitat banking and biodiversity offsets in the English land use planning system. Dorset: GreenHouse.

Hejnowicz, A. P., Raffaelli, D. G., Rudd, M. A., \& White, P. C. L. (2014). Evaluating the outcomes of payments for ecosystem services programmes using a capital asset framework. Ecosystem Services, 9 , 83-97. doi:10.1016/j.ecoser.2014.05.001.

Helm, D., \& Hepburn, C. (Eds.). (2014). Nature in the balance: The economics of biodiversity (1st ed.). Oxford: Oxford University Press.

Howley, P. (2015). The happy farmer: The effect of nonpecuniary benefits on behavior. American Journal of Agricultural Economics, 97(4), 1072-1086. doi:10.1093/ajae/aav020.

Howley, P., Buckley, C., Donoghue, C. O., \& Ryan, M. (2015). Explaining the economic "irrationality" of farmers' land use behaviour: The role of productivist attitudes and non-pecuniary benefits. Ecological Economics, 109, 186-193. doi:10.1016/j.ecolecon.2014.11.015.

Igoe, J., \& Brockington, D. (2007). Neoliberal conservation: A brief introduction. Conservation and Society, 5(4), 432-449.

Kellert, S. R., Mehta, J. N., Ebbin, S. A., \& Lichtenfeld, L. L. (2000). Community natural resource management: Promise, rhetoric, and reality. Society and Natural Resources, 13(8), 705-715. doi:10. 1080/089419200750035575.

Kettlewell, C. I., Bouchard, V., Porej, D., Micacchion, M., Mack, J. J., White, D., et al. (2008). An assessment of wetland impacts and compensatory mitigation in the Cuyahoga River Watershed, Ohio, USA. Wetlands, 28(1), 57-67. doi:10.1672/07-01.1.

Kettunen, M., \& Vihervaara, P. (2012). Socio-economic importance of ecosystem services in the nordic countries synthesis in the context of the economics of ecosystems and biodiversity (TEEB). Copenhagen: Nordic Council of Ministers.

Kiss, A. (2004). Is community-based ecotourism a good use of biodiversity conservation funds? Trends in Ecology and Evolution, 19(5), 232-237. doi:10.1016/j.tree.2004.03.010.

Klinsky, S. (2015). Justice and boundary setting in greenhouse gas cap and trade policy: A case study of the Western Climate Initiative. Annals of the Association of American Geographers, 105(1), 105-122. doi:10.1080/00045608.2014.960043.

Knox-Hayes, J. (2010). Constructing carbon market spacetime: Climate change and the onset of neomodernity. Annals of the Association of American Geographers, 100(4), 953-962. doi:10.1080/ 00045608.2010 .500554 .

Landell-Mills, N., \& Porras, I. (2002). Silver bullet or fools' gold: A global review of markets for forest environmental services and their impacts on the poor. Instruments for sustainable private sector forestry series. London: International Institute for Environment and Development.

Laurance, W. F., et al. (2015). Reducing the global environmental impacts of rapid infrastructure expansion. Current Biology, 25(7), R259-R262. doi:10.1016/j.cub.2015.02.050.

Lawton, J., Brotherton, P. N., Brown, V., Elphick, C., Fitter, A., Forshaw, J., et al. (2010). Making space for nature: A review of England's wildlife sites and ecological network. Report to Defra.

Maron, M., Dunn, P. K., McAlpine, C. A., \& Apan, A. (2010). Can offsets really compensate for habitat removal? The case of the endangered red-tailed black-cockatoo. Journal of Applied Ecology, 47(2), 348-355. doi:10.1111/j.1365-2664.2010.01787.x.

Maron, M., Ives, C. D., Kujala, H., Bull, J. W., Maseyk, F. J. F., Bekessy, S., et al. (2016). Taming a wicked problem: Resolving controversies in biodiversity offsetting. BioScience, 66, 489-498. doi:10.1093/ biosci/biw038.

McAfee, K. (2012). The contradictory logic of global ecosystem services markets. Development and Change, 43(1), 105-131. doi:10.1111/j.1467-7660.2011.01745.x. 
McCarthy, D. P., Donald, P. F., Scharlemann, J. P. W., Buchanan, G. M., Balmford, A., et al. (2012). Financial costs of meeting global biodiversity conservation targets: Current spending and unmet needs. Science, 338(6109), 946-949. doi:10.1126/science.1229803.

McCarthy, D., \& Morling, P. (2015). Using regulation as a last resort: Assessing the performance of voluntary approaches. Sandy: Royal Society for the Protection of Birds.

McCarthy, J., \& Prudham, S. (2004). Neoliberal nature and the nature of neoliberalism. Geoforum, 35(3), 275-283. doi:10.1016/j.geoforum.2003.07.003.

McCracken, M. E., Woodcock, B. A., Lobley, M., Pywell, R. F., Saratsi, E., et al. (2015). Social and ecological drivers of success in agri-environment schemes: The roles of farmers and environmental context. Journal of Applied Ecology, 52(3), 696-705. doi:10.1111/1365-2664.12412.

Moilanen, A., van Teeffelen, A. J. A., Ben-Haim, Y., \& Ferrier, S. (2009). How much compensation is enough? A framework for incorporating uncertainty and time discounting when calculating offset ratios for impacted habitat. Restoration Ecology, 17(4), 470-478. doi:10.1111/j.1526-100X.2008. 00382.x.

Mol, A. P. J., Sonnenfeld, D. A., \& Spaargaren, G. (Eds.). (2009). The ecological modernisation reader: Environmental reform in theory and practice. London and New York: Routledge.

OECD. (2016). Biodiversity Offsets. Paris: OECD Publishing.

Oliver, T. H., Isaac, N. J. B., August, T. A., Woodcock, B. A., Roy, D. B., \& Bullock, J. M. (2015). Declining resilience of ecosystem functions under biodiversity loss. Nature Communications, 6, 10122. doi:10.1038/ncomms10122.

Pautz, M. C., \& Wamsley, C. S. (2012). Pursuing trust in environmental regulatory interactions: The significance of inspectors' interactions with the regulated community. Administration and Society, 44(7), 853-884. doi:10.1177/0095399711429108.

Pickett, E. J., Stockwell, M. P., Bower, D. S., Garnham, J. I., Pollard, C. J., Clulow, J., et al. (2013). Achieving no net loss in habitat offset of a threatened frog required high offset ratio and intensive monitoring. Biological Conservation, 157, 156-162. doi:10.1016/j.biocon.2012.09.014.

Pilgrim, J. D., Brownlie, S., Ekstrom, J. M. M., Gardner, T. A., von Hase, A., et al. (2013). A process for assessing the offsetability of biodiversity impacts: Offsetability of biodiversity impacts. Conservation Letters. doi:10.1111/conl.12002.

Pirard, R. (2012). Market-based instruments for biodiversity and ecosystem services: A lexicon. Environmental Science \& Policy, 19-20, 59-68.

Pokorny, B., Scholz, I., \& de Jong, W. (2013). REDD+ for the poor or the poor for REDD+? About the limitations of environmental policies in the Amazon and the potential of achieving environmental goals through pro-poor policies. Ecology and Society. doi:10.5751/ES-05458-180203.

Rainey, H. J., Pollard, E. H. B., Dutson, G., Ekstrom, J. M. M., Livingstone, S. R., Temple, H. J., et al. (2015). A review of corporate goals of no net loss and net positive impact on biodiversity. Oryx, 49(2), 232-238. doi:10.1017/S0030605313001476.

Redford, K. H., \& William, M. A. (2009). Payment for ecosystem services and the challenge of saving nature. Conservation Biology, 23(4), 785-787. doi:10.1111/j.1523-1739.2009.01271.x.

Redpath, S. M., Young, J., Evely, A., Adams, W. M., Sutherland, W. J., Whitehouse, A., et al. (2013). Understanding and managing conservation conflicts. Trends in Ecology and Evolution, 28, 100-109. doi:10.1016/j.tree.2012.08.021.

Reed, M. S. (2008). Stakeholder participation for environmental management: A literature review. Biological Conservation, 141, 2417-2431. doi:10.1016/j.biocon.2008.07.014.

Reid, C. T. (2011). The privatisation of biodiversity? Possible new approaches to nature conservation law in the UK. Journal of Environmental Law, 23(2), 203-231. doi:10.1093/jel/eqr005.

Robertson, M. M. (2000). No net loss: Wetland restoration and the incomplete capitalization of nature. Antipode, 32(4), 463-493. doi:10.1111/1467-8330.00146.

Robertson, M. M. (2004). The neoliberalization of ecosystem services: Wetland mitigation banking and problems in environmental governance. Geoforum, 35(3), 361-373. doi:10.1016/j.geoforum.2003.06. 002 .

Robertson, M. M. (2006a). The nature that capital can see: Science, state, and market in the commodification of ecosystem services. Environment and Planning D: Society and Space, 24(3), 367-387. doi:10.1068/ d3304.

Robertson, M. M. (2006b). The nature that capital can see: Science, state, and market in the commodification of ecosystem services. Environment and Planning D: Society and Space, 24, 367-387. doi:10. $1068 / \mathrm{d} 3304$.

Robertson, M. (2012). Measurement and alienation: Making a world of ecosystem services. Transactions of the Institute of British Geographers, 37(3), 386-401. 
Robertson, M., \& Hayden, N. (2008). Evaluation of a market in wetland credits: Entrepreneurial wetland banking in Chicago. Conservation Biology, 22(3), 636-646. doi:10.1111/j.1523-1739.2008.00963.x.

Robinson, J. G. (2006). Conservation biology and real-world conservation. Conservation Biology, 20(3), 658-669. doi:10.1111/j.1523-1739.2006.00469.x.

Roth, R. J., \& Dressler, W. (2012). Market-oriented conservation governance: The particularities of place. Geoforum, 43(3), 363-366. doi:10.1016/j.geoforum.2012.01.006.

Sandbrook, C. (2015). What is conservation? Oryx, 49(4), 565-566. doi:10.1017/S0030605315000952.

Santangeli, A., Arroyo, B., Dicks, L. V., Herzon, I., Kukkala, A. S., Sutherland, W. J., et al. (2016). Voluntary non-monetary approaches for implementing conservation. Biological Conservation, 197, 209-214. doi:10.1016/j.biocon.2016.03.013.

Segerson, K. (2013). Voluntary approaches to environmental protection and resource management. Annual Review Resource Economics, 5, 161-180. doi:10.1146/annurev-resource-091912-151945.

Spash, C. L. (2015). Bulldozing biodiversity: The economics of offsets and trading-in nature. Biological Conservation, 192, 541-551. doi:10.1016/j.biocon.2015.07.037.

Strauss, A. L., Corbin, J. M. (1991). Basics of qualitative research: grounded theory procedures and techniques, 3. printing. ed. Sage: Newbury Park.

Sullivan, S. (2012). Financialisation, biodiversity conservation and equity: Some currents and concerns. Environment and development series (Vol. 16). Penang: Third World Network.

Sullivan, S., \& Hannis, M. (2015). Nets and frames, losses and gains: Value struggles in engagements with biodiversity offsetting policy in England. Ecosystem Services, 15, 162-173. doi:10.1016/j.ecoser.2015. 01.009.

Sutherland, W. J., et al. (2006). The identification of 100 ecological questions of high policy relevance in the UK. Journal of Applied Ecology, 43(4), 617-627. doi:10.1111/j.1365-2664.2006.01188.x.

Tallis, H., \& Lubchenco, J. (2014). Working together: A call for inclusive conservation. Nature, 515(7525), 27-28. doi:10.1038/515027a.

TEEB. (2008). The economics of ecosystems and biodiversity: An interim report. Brussels: European Communities.

Tittensor, D. P., et al. (2014). A mid-term analysis of progress toward international biodiversity targets. Science, 346(6206), 241-244. doi:10.1126/science.1257484.

Tregidga, H. (2013). Biodiversity offsetting: Problematisation of an emerging governance regime. Accounting, Auditing and Accountability Journal, 26, 806-832. doi:10.1108/AAAJ-02-2013-1234.

UK National Farmers' Union (2013). Biodiversity offsetting consultation response. http://www.nfuonline. com/assets/19774.

UN Economic and Social Council (2016). Report of the inter-agency and expert group on sustainable development goal indicators. http://unstats.un.org/unsd/statcom/47th-session/documents/2016-2IAEG-SDGs-Rev1-E.pdf.

von Hase, A., \& ten Kate, K. (2017). Correct framing of biodiversity offsets and conservation: A response to Apostolopoulou \& Adams. Oryx, 51, 32-34. doi:10.1017/S0030605316001022.

Waylen, K. A., Fischer, A., Mcgowan, P. J. K., Thirgood, S. J., \& Milner-Gulland, E. J. (2010). Effect of local cultural context on the success of community-based conservation interventions: Culture and conservation success. Conservation Biology, 24, 1119-1129. doi:10.1111/j.1523-1739.2010.01446.x.

Walker, D. (2006). Grounded Theory: An Exploration of Process and Procedure. Qualitative Health Research, 16(4), 547-559.

Walker, S., Brower, A. L., Stephens, R. T. T., Lee, W. G. (2009). Why bartering biodiversity fails. Conservation Letters, 2(4), 149-157.

Wissel, S., \& Wätzold, F. (2010). A conceptual analysis of the application of tradable permits to biodiversity conservation. Conservation Biology, 24(2), 404-411. doi:10.1111/j.1523-1739.2009.01444.x.

Young, S. C. (2015). The emergence of ecological modernisation: Integrating the environment and the economy?. London: Routledge. 